\title{
Indicators of soil quality in the implantation of no-till system with winter crops $^{1}$
}

\author{
Indicadores de qualidade de solo na implantação do sistema plantio direto com \\ culturas de inverno
}

\author{
Marco Antonio Nogueira ${ }^{2 *}$, Tiago Santos Telles ${ }^{3}$, Dáfila dos Santos Lima Fagotti ${ }^{4}$, Osmar Rodrigues Brito ${ }^{4}$, \\ Cássio Egídio Cavenaghi Prete ${ }^{4}$ e Maria de Fátima Guimarães ${ }^{4}$
}

\begin{abstract}
We assessed the effect of different winter crops on indicators of soil quality related to C and N cycling and C fractions in a Rhodic Kandiudult under no-till system at implantation, during two growing seasons, in Londrina PR Brazil. The experimental design was randomized blocks with split-plot in time arrangement, with four replications. The parcels were the winter crops: multicropping of cover crops with black oat (Avena strigosa), hairy vetch (Vicia villosa) and fodder radish (Raphanus sativus); sunflower (Heliantus annuus) intercropped with Urochloa ruziziensis; corn (Zea mays) intercropped with Urochloa; and corn; fodder radish; or wheat (Triticum aestivum) as sole crops. The subplots were the years: 2008 and 2009. Determinations consisted of total organic $\mathrm{C}$, labile and resistant $\mathrm{C}$, total $\mathrm{N}$, microbial biomass $\mathrm{C}$ and $\mathrm{N}$, the $\mathrm{C} / \mathrm{N}$ ratio of soil organic matter, and the microbial quotient $(q \mathrm{Mic}$ ), besides microbiological and biochemical attributes, assessed only in 2009 . The attributes significantly changed with the winter crops, especially the multicropping of cover crops and fodder radish, as well as effect of years. Despite stimulating the microbiological/biochemical activity, fodder radish cropping decreased the soil $\mathrm{C}$ in the second year, likewise the wheat cropping. The multicropping of cover crops in winter is an option for management in the establishment of no-till system, which contributes to increase the concentrations of $\mathrm{C}$ and stimulate the soil microbiological/biochemical activity.
\end{abstract}

Key words: Bioindicators. Organic Mater. Carbon. Microbial biomass.

RESUMO - Avaliaram-se os efeitos de diferentes culturas de inverno sobre indicadores de qualidade associados aos ciclos do $\mathrm{C}$ e do $\mathrm{N}$ e frações de $\mathrm{C}$ em um Nitossolo Vermelho eutroférrico, sob plantio direto em implantação, em dois anos agrícolas, em Londrina PR. O delineamento experimental foi em blocos ao acaso, com parcelas subdivididas no tempo, com quatro repetições. As parcelas foram constituídas pelas culturas de inverno: consórcio de aveia preta (Avena strigosa), ervilhaca peluda (Vicia villosa) e nabo forrageiro (Raphanus sativus); girassol (Helianthus annuus) consorciado com braquiária (Urochloa ruziziensis); milho (Zea mays) consorciado com braquiária; e as culturas solteiras de milho; nabo forrageiro; ou trigo (Triticum aestivum). As subparcelas foram os anos de avaliação: 2008 e 2009. Determinaram-se os teores de C total, C lábil e resistente, o N total, o C e o $\mathrm{N}$ da biomassa microbiana, a relação $\mathrm{C} / \mathrm{N}$ da matéria orgânica do solo, e o quociente microbiano do solo ( $q \mathrm{Mic}$ ), além de atributos microbiológicos e bioquímicos apenas no segundo ano. Os atributos foram significativamente alterados pelas culturas de inverno, sobretudo o consórcio de plantas de cobertura e nabo forrageiro, e pelas épocas de avaliação. Apesar de estimular a atividade microbiológica/bioquímica do solo, o cultivo de nabo diminuiu o teor de $\mathrm{C}$ do solo no segundo ano, similarmente ao cultivo de trigo. A combinação de espécies de plantas de cobertura de inverno é uma alternativa de manejo no estabelecimento do sistema de plantio direto, contribuindo para o aumento dos teores de $\mathrm{C}$ e estimular a atividade microbiológica/bioquímica do solo.

Palavras-chave: Bioindicadores. Matéria orgânica. Carbono. Biomassa microbiana.

\footnotetext{
*Autor para correspondência

${ }^{1}$ Recebido para publicação em 08/04/2014; aprovado em 25/09/2014

Parte do projeto 26150/2008, financiado com recursos CEPE/UEL

${ }^{2}$ Embrapa Soja, Rodovia Carlos João Strass, Distrito de Warta, Caixa Postal 231, Londrina-PR, Brasil, 86.001-970, marco.nogueira@embrapa.br ${ }^{3}$ Instituto Agronômico do Paraná, Caixa Postal 481, Londrina-PR, Brasil, 86.047-902, telles@iapar.br

${ }^{4}$ Departamento de Agronomia, Universidade Estadual de Londrina, Caixa Postal 6001, Londrina-PR, Brasil, CEP: 86.051-990, dafila.fagotti@gmail com,osmar@uel.br, cassio@uel.br,mfatima@uel.br
} 


\section{INTRODUCTION}

From the viewpoint of sustainable development, using winter cover crops is a tool for conservationist soil management like no-till system (NTS), with positive effects on attributes indicator of soil quality (CORDEIRO et al., 2012; GAMA-RODRIGUES et al., 2008). The soil mulching in winter increases the concentration of soil organic matter (SOM), improves the nutrient cycling, controls erosion, and mitigates nutrient leaching (ANGHINONI, 2007; SILVA et al., 2007). All these positive results favor the crop in succession and increase the efficiency of water and nutrient uses (SILVA et al., 2008), which are critical to improve the success of implantation of NTS.

The SOM is a key component of soil fertility; it has positive effects on soil chemical, physical and biological properties, improving the production system and yield (KASCHUK et al., 2010). Considering the soil chemical properties, SOM increases the cation exchange capacity (CEC), resulting in higher soil capacity to hold nutrients (ANGHINONI, 2007). From the physical view point, SOM increases the water holding capacity and aggregation of soil particles (FRANCHINI et al., 2012). In addition, is source of $\mathrm{C}$ and energy for microorganisms, increasing the microbial biomass and activity (CORDEIRO et al., 2012; SILVA et al., 2007). The soil microbial biomass works as transitory reservoir of nutrients originated from mineralization of SOM or fertilizers (CARDOSO et al., 2013), reducing losses like phosphate fixation and nitrate leaching (FAGOTTI et al., 2012; FRANK; GROFFMAN, 2009; RANGEL; SILVA, 2007). Considering that the speed of decomposition of plant residues rely on its chemical composition, mainly the $\mathrm{C}$ to $\mathrm{N}$ ratio and lignin content, the type of residue also affect the microbial activity and biomass (BINI et al., 2013; KUWANO et al., 2014).

As microbial biomass is easily changeable, it is considered a sensitive indicator of alterations imposed by soil use and management (BLAIR et al., 1995; NOGUEIRA et al., 2006). Consequently, has been suggested as biological indicator of soil quality related to the sustainability of the production system (BINI et al., 2014; CARDOSO et al., 2013; KASCHUK et al., 2010), and is more sensitive than the soil organic $\mathrm{C}$ (SOC) to indicate changes in quality of SOM (CARDOSO et al., 2013; GAMA-RODRIGUES et al., 2008).

The use of cover crops in winter and their effects on soil properties are important to adopt strategies for soil management, aiming at improvement of soil quality, especially under NTS during the summer cropping season. Each species may contribute differentially in terms of organic matter inputs, as well as on the quality of SOM, affecting attributes related to the soil quality (BINI $e t$ al., 2014; CORDEIRO et al., 2012; NOGUEIRA et al., 2006).
The aim of this work was to assess the effect of different winter crops on indicators of soil quality related to $\mathrm{C}$ and $\mathrm{N}$ cycling and fractions of $\mathrm{C}$ in a soil under NTS in the two first years of establishment.

\section{MATERIAL AND METHODS}

This work was carried out in 2008 and 2009 at Londrina-PR (2320' S; $51^{\circ} 12^{\prime}$ W, 575 m of elevation a.s.l.), in a clayey Rhodic Kandiudult (Soil Taxonomy, USDA), corresponding to Nitossolo Vermelho Eutroférrico (Brazilian classification) (EMBRAPA, 2006). The climate is classified as Cfa (humid subtropical) (Köppen), with hot summers, non-frequent frost, predominance of rainfall during the summer, but without well-defined dry season. The average annual temperature and rainfall are $21{ }^{\circ} \mathrm{C}$ and $1608 \mathrm{~mm}$, respectively, and results along the two years of study are shown in Figure 1. The site had been managed under conventional tillage, with succession between soybean (Glycine max L.) or corn (Zea mays L.) in summer and wheat (Triticum aestivum L.) or corn in winter, for about 20 yrs before the installation of the trial.

The experiment was conducted as completely randomized blocks, arranged as split-plot in time, with four replications. The treatments in the parcels were: multicropping of cover crops with black oat (Avena strigosa), hairy vetch (Vicia villosa) and fodder radish cv. IPR-116 (Raphanus sativus); sunflower (Helianthus annuus) intercropped with Urochloa ruziziensis; corn (Zea mays) intercropped with $U$. ruziziensis; and single crops with corn; fodder radish; and wheat cv. CD-104 (Triticum aestivum). The years of evaluation were considered as subparcels.

In 2008 summer season, the area had been cropped with corn that yielded $6000 \mathrm{~kg} \mathrm{ha}^{-1}$ of grains. Before the installation of the winter crops, lime was applied to raise base saturation to $70 \%$ at $0-20 \mathrm{~cm}$ of soil depth and addition of $600 \mathrm{~kg} \mathrm{ha}^{-1}$ of simple superphosphate $\left(180 \mathrm{~g} \mathrm{~kg}^{-1}\right.$ of $\mathrm{P}_{2} \mathrm{O}_{5}, 160 \mathrm{~g} \mathrm{~kg}^{-1}$ of $\mathrm{Ca}$, and $120 \mathrm{~g} \mathrm{~kg}^{-1}$ of $\mathrm{S}$ ) distributed on the soil surface. To control weeds, $980 \mathrm{~g}^{2} \mathrm{i} \mathrm{ha}^{-1}$ of glyphosate was applied. The winter crops were sown in April 2008 on $30 \mathrm{~m} \times 10 \mathrm{~m}$ plots, considered the very beginning of the NTS; in 2009 the sowing was made under NTS on the same plots.

The winter cover crops were mechanically crushed at the full flowering and left on the soil surface, while the cash crops, corn and wheat, were conducted up to physiological maturation and harvested mechanically and their residues left on soil surface. Nine soil samples were taken in August 2008 and September 2009, between lines of the winter crops, at $0-0.10 \mathrm{~m}$ depth, pooled to form a composite sample, homogenized and sieved $(<2 \mathrm{~mm})$, and stored at field moisture at $4{ }^{\circ} \mathrm{C}$ for microbiological 
Figure 1 - Monthly temperature and rainfall during the conduction of the trial, at Londrina PR, in 2008 and 2009

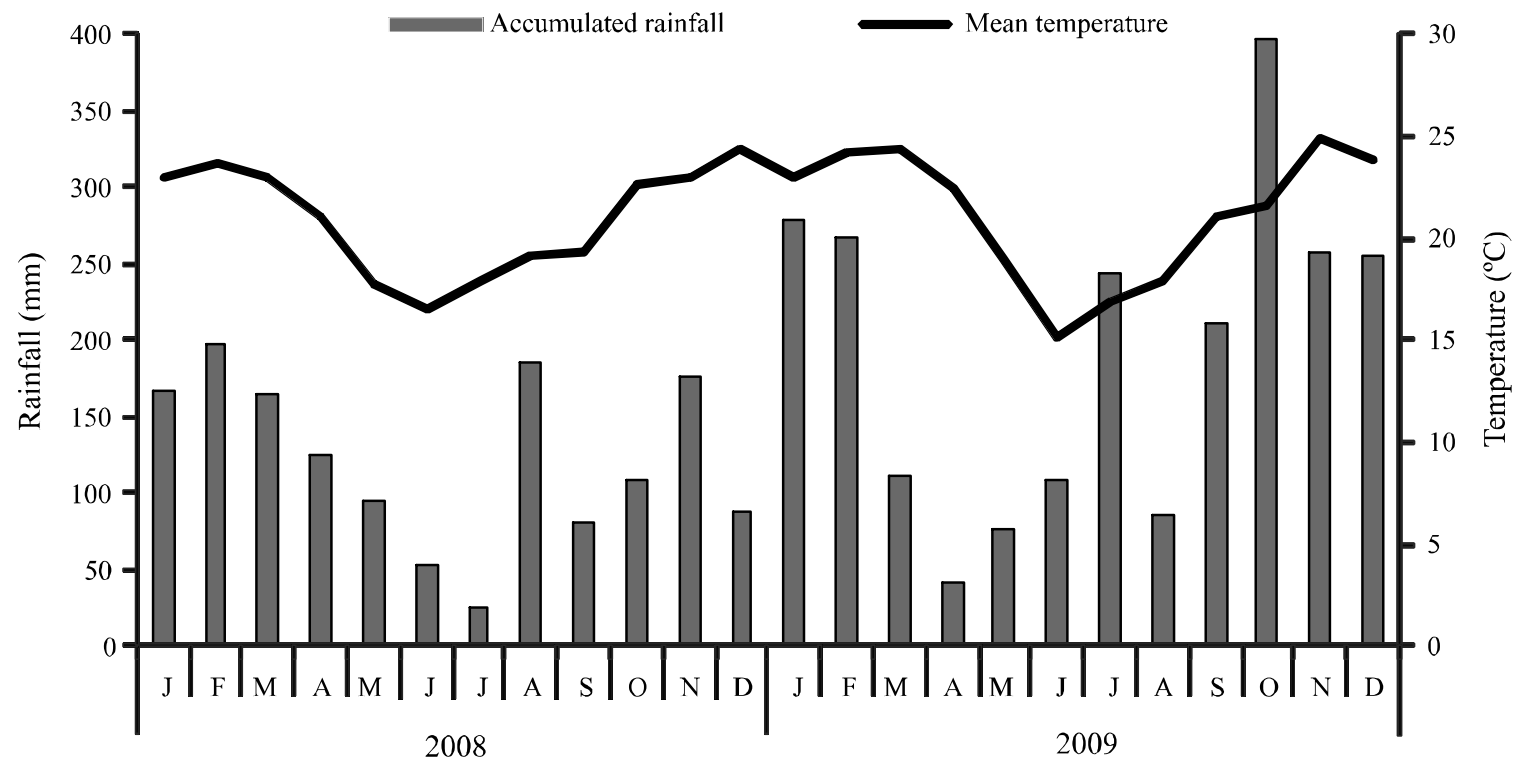

analysis. Besides microbial biomass carbon and nitrogen, further microbiological and biochemical analysis were made only in 2009. Analysis for soil chemical attributes were made on air-dried soil samples (PAVAN et al., 1992); the total organic carbon (TOC) was determined by Walkley-Black method (EMBRAPA, 2009); labile carbon (L-C) according to Blair et al. (1995), and the resistant carbon (R-C) estimated by the difference between TOC and L-C. The microbial biomass carbon (MBC) and nitrogen (MBN) were determined by fumigation-extraction method (VANCE et al., 1987; BROOKES et al., 1985). The determination of NBM in the extracts and total N (TN) in soil were determined by titration after sulfuric digestion at $350{ }^{\circ} \mathrm{C}$ via semi-micro-Kjeldahl method (BREMNER; MULVANEY, 1982). The microbial quotient ( $q \mathrm{Mic})$ was calculated as the ratio between $\mathrm{MBC}$ and $\mathrm{TOC}[q \mathrm{Mic}=$ $(\mathrm{MBC} / \mathrm{TOC}) \times 100]($ SPARLING, 1992).

In 2009, further microbiological and biochemical analyses were performed. Basal respiration was determined based on the $\mathrm{CO}_{2}$ released and trapped in a $0.05 \mathrm{~mol} \mathrm{~L}^{-1}$ sodium hydroxide solution during $72 \mathrm{~h}$ of incubation in hermetically closed vials, at $28{ }^{\circ} \mathrm{C}$ in the dark (ALEF, 1995). The acid phosphatase activity was based on the hydrolysis of p-nitrophenyl phosphate (0.05 mol L-1) (TABATABAI; BREMNER, 1969). The dehydrogenase activity was based on the use of $15 \mathrm{~g} \mathrm{~L}^{-1}$ triphenyl tetrazolium chloride (TTC) solution as substrate, and measured as triphenyl tetrazolium formazan (TTF) after incubation for $24 \mathrm{~h}$ at $37^{\circ} \mathrm{C}$ in the dark (CASIDA JR et al., 1964). The activities of urease and asparaginase were quantified after incubation in sodium acetate buffer with the respective substrate $\left(0.05 \mathrm{~mol} \mathrm{~L}^{-1}\right.$ trishydroxymethyl amino-methane - THAM pH 9 and $1 \mathrm{~mL}$ of $0.2 \mathrm{~mol} \mathrm{~L}-1$ urea solution, or $0.1 \mathrm{~mol} \mathrm{~L}^{-1} \mathrm{THAM} \mathrm{pH} 10$ and $1 \mathrm{~mL}$ of $0.5 \mathrm{~mol} \mathrm{~L}^{-1}$ of L-asparagine, respectively) (TABATABAI; BREMNER, 1972; FRANKENBERGER; TABATABAI, 1991). The cellulase activity was assessed in samples incubated in phosphate buffer $\mathrm{pH} 5.5$ in the presence of caboxymethyl cellulose as substrate, for $24 \mathrm{~h}$ at $50{ }^{\circ} \mathrm{C}$ in the dark (SCHINNER; VON MERSI, 1990). Ammonification and nitrification rates were determined based on the concentrations of ammonium- $\mathrm{N}$ and nitrate$\mathrm{N}$ before and after incubation in hermetically closed vials at $28^{\circ} \mathrm{C}$ for $21 \mathrm{~d}$ in the dark, added or not with ammonium sulfate before incubation (SCHUSTER; SCHRODER, 1990). Ammonium- $\mathrm{N}$ and nitrate- $\mathrm{N}$ were determined in 2 mol L ${ }^{-1}$ potassium chloride extracts by titration after semi-micro-Kjeldahl distillation (KEENEY; NELSON, 1982).

Results for soil chemical analysis, C fractions, and $\mathrm{N}$ and $\mathrm{C}$ microbial biomasses were submitted to ANOVA according to a randomized block design with split-plot in time arrangement (2008 and 2009). The remaining microbial attributes assessed only in 2009 were analyzed according to a randomized block design. Means were compared by Tukey's test $(p \leq 0.05)$, with the software $\mathrm{SAS}^{\odot} 9.3$ version. A principal component analysis (PCA) was also performed with the data obtained in 2009, with the objective to assess the relation among the variables and their relations with the treatments, by using the software Canoco 4.5 for Windows $^{\mathrm{TM}}$. 


\section{RESULTS AND DISCUSSION}

The winter cops had minor effects on soil chemical attributes; in 2008 there was effect only on $\mathrm{pH}, \mathrm{Mg}^{2+}$ and $\mathrm{K}^{+}$(Table 1). In 2009 there was effect on exchangeable $\mathrm{Al}^{3+}$, which decreased in the soil cropped with fodder radish $(\mathrm{R})$ compared to the soil with sunflower + Urochloa. Considering the year, $\mathrm{Mn}^{2+}$ decreased from 2008 to 2009 in all treatments, $\mathrm{P}$ in five, $\mathrm{K}^{+}$in two, and $\mathrm{V} \%$ in three treatments, whereas the potential acidity $(\mathrm{H}+\mathrm{Al})$ increased in four out of six treatments. This is a natural process caused by successive cropping that act in the exportation of nutrients by harvests, immobilization in biomass, but also natural processes of loss, like $\mathrm{P}$ fixation and leaching of basis (ANGHINONI, 2007). No deep effects of winter crops were expected, since their use was recent, although effects may increase in the long-term.

The winter crops affected attributes related to $\mathrm{C}$ fractions and total $\mathrm{N}$ in soil, especially in 2008 (Table 2). Effects were also observed for microbiological and biochemical attributes assessed only in 2009 (Table 3). In 2008, the TOC had higher concentrations in the soil cropped with fodder radish and wheat, in comparison to the soil cropped with sunflower $+U$. ruziziensis. In 2009, the fodder radish and wheat-cropped soils had lower TOC contents as compared to the soil cropped to the multicropping of cover crops. There was also a decrease from 2008 to 2009 by $15 \%$ and $17 \%$ in the soils with fodder radish and wheat, respectively, in comparison to the soil cropped with the multicropping of cover crops. In 2008, the L-C had the highest concentration in the soils cropped with corn and sunflower $+U$. ruziziensis, again in comparison to the soil cropped with the multicropping of cover crops. In 2009, the soil cropped with the multicropping of cover crops showed higher concentrations of L-C, $79 \%$ higher than in 2008, and differed from the L-C in the soil cropped with fodder radish and wheat.

The treatments strongly affected the R-C in 2008, where the multicropping of cover crops, fodder radish and wheat resulted in higher $\mathrm{R}-\mathrm{C}$ compared to the remaining crops. Nevertheless, there was a decrease in the majority of treatments from 2008 to 2009, with no effects of winter crops in 2009, showing that treatments did not affect the more resistant forms of soil $\mathrm{C}$ in 2009 . The concentrations of L-C that were lower than R-C in 2008 inverted in 2009, what might be related to the different degrees of transformation of organic residues that derive these fractions of soil C (RANGEL; SILVA, 2007). In 2008, the lower concentration of L-C compared to R-C suggest higher degree of humification, whereas in 2009 the higher

Table 1 - Chemical attributes of a Rhodic Kandiudult as affected by different winter crops in a no-till cropping system under implantation. Londrina PR, 2008 and 2009

\begin{tabular}{|c|c|c|c|c|c|c|c|c|}
\hline \multirow{2}{*}{ Treatment } & \multirow{2}{*}{$\mathrm{pH}\left(\mathrm{CaCl}_{2}\right)$} & $\mathrm{P}$ & $\mathrm{Al}^{+3}$ & $\mathrm{Ca}^{+2}$ & $\mathrm{Mg}^{+2}$ & $\mathrm{~K}^{+}$ & $\mathrm{H}+\mathrm{Al}$ & $\mathrm{V}$ \\
\hline & & $\mathrm{mg} \mathrm{dm}^{-3}$ & - & \multicolumn{4}{|c|}{ 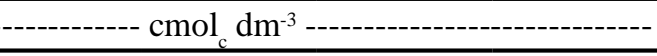 } & $\%$ \\
\hline \multicolumn{9}{|c|}{2008} \\
\hline Cover crops ${ }^{1}$ & $5.8 \mathrm{abA}$ & $35.2 \mathrm{aA}$ & $0.01 \mathrm{aA}$ & $7.6 \mathrm{aA}$ & $2.7 \mathrm{bA}$ & $1.3 \mathrm{abcA}$ & $3.0 \mathrm{aB}$ & $79 \mathrm{aA}$ \\
\hline Sunflower+Ur ${ }^{2}$ & $5.7 \mathrm{bA}$ & $25.8 \mathrm{aA}$ & $0.04 \mathrm{aA}$ & $6.7 \mathrm{aA}$ & $3.0 \mathrm{abA}$ & $1.4 \mathrm{aA}$ & $3.4 \mathrm{aB}$ & $77 \mathrm{aA}$ \\
\hline Corn & $5.7 \mathrm{bA}$ & $29.4 \mathrm{aA}$ & $0.05 \mathrm{aA}$ & $7.7 \mathrm{aA}$ & $3.1 \mathrm{abA}$ & $1.4 \mathrm{abA}$ & $3.2 \mathrm{aB}$ & $79 \mathrm{aA}$ \\
\hline Corn+Ur & $5.8 \mathrm{abA}$ & $31.5 \mathrm{aA}$ & $0.04 \mathrm{aA}$ & $7.1 \mathrm{aA}$ & $3.1 \mathrm{abA}$ & $1.1 \mathrm{cA}$ & $3.2 \mathrm{aB}$ & $78 \mathrm{aA}$ \\
\hline Fodder radish & $5.8 \mathrm{abA}$ & $35.9 \mathrm{aA}$ & $0.03 \mathrm{aA}$ & $7.5 \mathrm{aA}$ & $3.0 \mathrm{abA}$ & $1.2 \mathrm{cA}$ & $3.3 \mathrm{aA}$ & $78 \mathrm{aA}$ \\
\hline Wheat & $5.9 \mathrm{aA}$ & $32.1 \mathrm{aA}$ & $0.04 \mathrm{aA}$ & $6.6 \mathrm{aA}$ & $3.3 \mathrm{aA}$ & $1.3 \mathrm{bcA}$ & $3.3 \mathrm{aA}$ & $77 \mathrm{aA}$ \\
\hline \multicolumn{9}{|c|}{2009} \\
\hline Cover crops ${ }^{1}$ & $5.7 \mathrm{aA}$ & $24.9 \mathrm{aB}$ & $0.03 \mathrm{abA}$ & $7.6 \mathrm{aA}$ & $1.8 \mathrm{aB}$ & $1.2 \mathrm{aA}$ & $4.1 \mathrm{aA}$ & $72 \mathrm{aB}$ \\
\hline Sunflower+Ur ${ }^{2}$ & $5.6 \mathrm{aA}$ & $24.6 \mathrm{aA}$ & $0.05 \mathrm{aA}$ & $7.6 \mathrm{aA}$ & $1.9 \mathrm{aB}$ & $1.3 \mathrm{aB}$ & $4.0 \mathrm{aA}$ & $73 \mathrm{aA}$ \\
\hline Corn & $5.6 \mathrm{aA}$ & $21.8 \mathrm{aB}$ & $0.03 \mathrm{abA}$ & $7.6 \mathrm{aA}$ & $2.0 \mathrm{aB}$ & $1.2 \mathrm{aB}$ & $4.0 \mathrm{aA}$ & $73 \mathrm{aB}$ \\
\hline Corn+Ur & $5.6 \mathrm{aB}$ & $23.3 \mathrm{aB}$ & $0.03 \mathrm{abA}$ & $7.9 \mathrm{aA}$ & $1.9 \mathrm{aB}$ & $1.2 \mathrm{aA}$ & $3.8 \mathrm{aA}$ & $74 \mathrm{aA}$ \\
\hline Fodder radish & $5.7 \mathrm{aA}$ & $26.7 \mathrm{aB}$ & $0.02 \mathrm{bA}$ & $7.4 \mathrm{aA}$ & $1.9 \mathrm{aB}$ & $1.3 \mathrm{aA}$ & $3.6 \mathrm{aA}$ & $74 \mathrm{aA}$ \\
\hline Wheat & $5.7 \mathrm{aB}$ & $24.7 \mathrm{aB}$ & $0.02 \mathrm{abA}$ & $7.1 \mathrm{aA}$ & $1.8 \mathrm{aB}$ & $1.2 \mathrm{aA}$ & $3.8 \mathrm{aA}$ & $73 \mathrm{aB}$ \\
\hline
\end{tabular}

Small letters in columns compare the effect of winter crops within the same year, whereas capital letters compare the effect of years within the same winter crop (Tukey, 5\%). ${ }^{1}$ Multicropping of cover crops: black oat (Avena strigosa), hairy vetch (Vicia villosa) and fodder radish (Raphanus sativus);

${ }^{2}$ Urochloa ruziziensis intercropped with the main crop 
concentration of L-C suggest less humification, resulting in predominance of more labile $\mathrm{C}$ fractions. Changes in concentrations of organic $\mathrm{C}$ fractions in soil depend on the balance between formation and mineralization of
SOM, which is mediated by the microbial community (BINI et al., 2013; NOGUEIRA et al., 2006). Easily degradable residues, like fodder radish residues, stimulate the microbial activity, which may lead to mineralization

Table 2 - Concentrations of total organic carbon (TOC), labile carbon (L-C), resistant carbon (R-C), microbial biomass carbon (MBC), microbial quotient $(q \mathrm{Mic})$, total nitrogen $(\mathrm{T}-\mathrm{N}), \mathrm{C} / \mathrm{N}$ ratio of soil organic matter $(\mathrm{C} / \mathrm{N}-\mathrm{SOM})$, and microbial biomass nitrogen $(\mathrm{MBN})$ in a Rhodic Kandiudult as affected by different winter crops in a no-till cropping system under implantation. Londrina-PR, 2008 and 2009

\begin{tabular}{|c|c|c|c|c|c|c|c|c|}
\hline \multirow{2}{*}{ Treatment } & TOC & $\mathrm{L}-\mathrm{C}$ & $\mathrm{R}-\mathrm{C}$ & $\mathrm{MBC}$ & qMic & $\mathrm{T}-\mathrm{N}$ & \multirow{2}{*}{$\mathrm{C} / \mathrm{N}-\mathrm{SOM}$} & MBN \\
\hline & \multicolumn{3}{|c|}{ 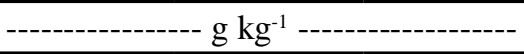 } & $\mathrm{mg} \mathrm{kg}^{-1}$ & $\%$ & $\mathrm{~g} \mathrm{~kg}^{-1}$ & & $\mathrm{mg} \mathrm{kg}^{-1}$ \\
\hline \multicolumn{9}{|c|}{2008} \\
\hline Cover crops $^{1}$ & $20.7 \mathrm{abA}$ & $7.3 \mathrm{bB}$ & $13.3 \mathrm{aA}$ & $641.9 \mathrm{abA}$ & $3.18 \mathrm{abA}$ & $1.9 \mathrm{bA}$ & $10.8 \mathrm{aA}$ & $48.6 \mathrm{abA}$ \\
\hline Sunflower+Ur ${ }^{2}$ & $18.9 \mathrm{bA}$ & $9.5 \mathrm{aA}$ & $9.4 \mathrm{cA}$ & $438.4 \mathrm{cA}$ & $2.34 \mathrm{bcA}$ & $2.0 \mathrm{abA}$ & $9.5 \mathrm{bA}$ & $16.7 \mathrm{~dB}$ \\
\hline Corn & $20.3 \mathrm{abA}$ & $10.0 \mathrm{aA}$ & $10.3 \mathrm{bA}$ & $509.4 \mathrm{bcA}$ & $2.52 \mathrm{bcA}$ & $2.0 \mathrm{abA}$ & $10.2 \mathrm{abA}$ & $41.5 \mathrm{bcA}$ \\
\hline Corn+Ur & $19.7 \mathrm{abA}$ & $9.1 \mathrm{abA}$ & $10.6 \mathrm{bA}$ & $460.6 \mathrm{cA}$ & $2.34 \mathrm{bcA}$ & $1.9 \mathrm{bA}$ & $10.6 \mathrm{aA}$ & $18.0 \mathrm{~dB}$ \\
\hline Fodder radish & $21.6 \mathrm{aA}$ & $8.4 \mathrm{abA}$ & $13.2 \mathrm{aA}$ & $794.3 \mathrm{aA}$ & $3.69 \mathrm{aA}$ & $2.2 \mathrm{aA}$ & $10.8 \mathrm{aA}$ & $57.9 \mathrm{aA}$ \\
\hline Wheat & $21.6 \mathrm{aA}$ & $8.2 \mathrm{abA}$ & $13.4 \mathrm{aA}$ & $482.8 \mathrm{cA}$ & $2.23 \mathrm{cA}$ & $2.1 \mathrm{abA}$ & $10.3 \mathrm{abA}$ & $32.8 \mathrm{cA}$ \\
\hline \multicolumn{9}{|c|}{2009} \\
\hline Cover crops $^{1}$ & $21.1 \mathrm{aA}$ & $13.1 \mathrm{aA}$ & $8.0 \mathrm{aB}$ & $473.4 \mathrm{aB}$ & $2.25 \mathrm{aB}$ & $2.0 \mathrm{abA}$ & $10.8 \mathrm{aA}$ & $35.3 \mathrm{aB}$ \\
\hline Sunflower+Ur ${ }^{2}$ & $18.9 \mathrm{abA}$ & $12.1 \mathrm{abA}$ & $6.9 \mathrm{aA}$ & $552.8 \mathrm{aA}$ & $2.92 \mathrm{aA}$ & $2.0 \mathrm{aA}$ & $9.4 \mathrm{cA}$ & $40.8 \mathrm{aA}$ \\
\hline Corn & $20.0 \mathrm{abA}$ & $12.4 \mathrm{abA}$ & $7.5 \mathrm{aA}$ & $433.5 \mathrm{aA}$ & $2.18 \mathrm{aA}$ & $1.9 \mathrm{abA}$ & $10.3 \mathrm{abcA}$ & $35.3 \mathrm{aA}$ \\
\hline Corn+Ur & $19.3 \mathrm{abA}$ & $11.8 \mathrm{abA}$ & $7.5 \mathrm{aB}$ & $482.8 \mathrm{aA}$ & $2.52 \mathrm{aA}$ & $1.8 \mathrm{abA}$ & $10.7 \mathrm{abA}$ & $34.3 \mathrm{aA}$ \\
\hline Fodder radish & $18.4 \mathrm{bB}$ & $10.9 \mathrm{bA}$ & $7.5 \mathrm{aB}$ & $462.8 \mathrm{aB}$ & $2.51 \mathrm{aB}$ & $1.9 \mathrm{abB}$ & $9.7 \mathrm{bcB}$ & $31.1 \mathrm{aB}$ \\
\hline Wheat & $17.9 \mathrm{bB}$ & $10.3 \mathrm{bA}$ & $7.6 \mathrm{aB}$ & $459.3 \mathrm{aA}$ & $2.56 \mathrm{aA}$ & $1.7 \mathrm{bB}$ & $10.4 \mathrm{abA}$ & $31.2 \mathrm{aA}$ \\
\hline
\end{tabular}

Small letters in columns compare the effect of winter crops within the same year, whereas capital letters compare the effect of years within the same winter crop (Tukey, 5\%). 'Multicropping of cover crops: black oat (Avena strigosa), hairy vetch (Vicia villosa) and fodder radish (Raphanus sativus);

${ }^{2}$ Urochloa ruziziensis intercropped with the main crop

Table 3 - Microbiological and biochemical attributes of a Rhodic Kandiudult as affected by different winter crops in a no-till cropping system under implantation. Londrina-PR, 2009

\begin{tabular}{|c|c|c|c|c|c|c|c|c|}
\hline \multirow{2}{*}{ Treatment } & Cellulase & $\begin{array}{l}\text { Dehydroge- } \\
\text { nase }\end{array}$ & Respiration & Asparaginase & Urease & $\begin{array}{l}\text { Ammonifica- } \\
\text { tion rate }\end{array}$ & $\begin{array}{c}\text { Acid } \\
\text { phoshatase }\end{array}$ & $\begin{array}{l}\text { Nitrification } \\
\quad \text { rate }\end{array}$ \\
\hline & $\begin{array}{c}\mathrm{mg} \mathrm{kg}^{-1} \text { of } \\
\mathrm{RS} \mathrm{d}^{-1} \\
\end{array}$ & $\begin{array}{c}\mathrm{mg} \mathrm{kg}^{-1} \text { of } \\
\mathrm{TTF} \mathrm{d}^{-1}\end{array}$ & $\begin{array}{l}\mathrm{mg} \mathrm{kg}^{-1} \text { of } \\
\mathrm{CO}_{2}-\mathrm{C} \mathrm{d}^{-1} \\
\end{array}$ & $\begin{array}{c}\mathrm{mg} \mathrm{kg}^{-1} \text { of } \\
\mathrm{NH}_{4}^{+}-\mathrm{N} 2 \mathrm{~h}^{-1}\end{array}$ & $\begin{array}{c}\mathrm{mg} \mathrm{kg}^{-1} \text { of } \\
\mathrm{NH}_{4}^{+}-\mathrm{N} 2 \mathrm{~h}^{-1}\end{array}$ & $\begin{array}{l}\mathrm{mg} \mathrm{kg}^{-1} \text { of } \\
\mathrm{NH}_{4}^{+}-\mathrm{N} \mathrm{d}^{-1}\end{array}$ & $\begin{array}{c}\mathrm{mg} \mathrm{kg}^{-1} \text { of } \\
\mathrm{PNF} \mathrm{h}^{-1}\end{array}$ & $\begin{array}{l}\mathrm{mg} \mathrm{kg}^{-1} \text { of } \\
\mathrm{NO}_{3}^{-}-\mathrm{N} \mathrm{d}^{-1}\end{array}$ \\
\hline C. crops $^{1}$ & $180 \mathrm{~b}$ & $13 \mathrm{~b}$ & $19.4 \mathrm{ab}$ & $18.6 \mathrm{a}$ & $14.3 \mathrm{c}$ & $1.15 \mathrm{a}$ & $360 \mathrm{a}$ & $0.83 \mathrm{a}$ \\
\hline Sunfl.+Ur ${ }^{2}$ & $247 \mathrm{ab}$ & $14 \mathrm{ab}$ & $18.4 \mathrm{ab}$ & $5.0 \mathrm{~b}$ & $36.3 \mathrm{a}$ & $1.13 \mathrm{ab}$ & $240 \mathrm{~b}$ & $0.85 \mathrm{a}$ \\
\hline Corn & $210 \mathrm{ab}$ & $14 \mathrm{ab}$ & $22.4 \mathrm{a}$ & $8.4 \mathrm{ab}$ & $28.1 \mathrm{ab}$ & $1.10 \mathrm{ab}$ & $351 \mathrm{a}$ & $0.80 \mathrm{a}$ \\
\hline Corn+Ur & $195 \mathrm{~b}$ & $12 \mathrm{~b}$ & $20.1 \mathrm{ab}$ & $16.4 \mathrm{a}$ & $22.7 \mathrm{bc}$ & $1.03 \mathrm{bc}$ & $299 a b$ & $0.78 \mathrm{a}$ \\
\hline F. radish ${ }^{3}$ & $283 \mathrm{a}$ & $17 \mathrm{a}$ & $16.1 \mathrm{~b}$ & $8.1 \mathrm{ab}$ & $29.6 \mathrm{ab}$ & $1.00 \mathrm{c}$ & $293 \mathrm{ab}$ & $0.70 \mathrm{a}$ \\
\hline Wheat & $199 \mathrm{~b}$ & $16 \mathrm{ab}$ & $15.2 \mathrm{~b}$ & $17.8 \mathrm{a}$ & $25.6 \mathrm{bc}$ & $1.00 \mathrm{c}$ & $279 \mathrm{ab}$ & $0.68 \mathrm{a}$ \\
\hline
\end{tabular}

Means followed by the same letters in columns do not differ each other (Tukey, $5 \%$ ). RS $=$ reducing sugars; TTF $=$ triphenyl tetrazolium formazan; PNF = p-nitrophenol. ${ }^{1}$ Multicropping of cover crops: black oat (Avena strigosa), hairy vetch (Vicia villosa) and fodder radish (Raphanus sativus); ${ }^{2}$ Urochloa ruziziensis intercropped with the main crop; ${ }^{3}$ Fodder radish 
of stable soil $\mathrm{C}$, starting with the more easily degradable fractions like L-C, and may reach, at lower extent, even the more stable $\mathrm{C}$ fractions like R-C. In agreement with this possibility, fodder radish and the multicropping of cover crops stimulated the MBC in 2008, in comparison to the soil with sunflower + Urochloa, corn in single crop or intercropped with Urochloa, and wheat (Table 3). The PCA also showed this behavior in 2009 (Figure 2), in which MBC was more related to the soil cropped with fodder radish, and at lower extent, with the multicropping of cover crops. There was no effect of winter crops on MBC in 2009, but there was a decrease from 2008 to 2009 by $26 \%$ and $42 \%$, respectively, in the treatments with the multicropping of cover crops, and fodder radish (Table 2). Soil management, climatic conditions, quality of residues like $\mathrm{C} / \mathrm{N}$ ratio and concentration of lignin, also affect the $\mathrm{MBC}$ and the balance among $\mathrm{C}$ fractions in soil (ANGHINONI, 2007; BINI et al., 2013; RANGEL; SILVA, 2007). The input of easily degradable residues like fodder radish stimulates the microbial community (SCHOMBERG; ENDALE, 2004), which may burn up the more easily degradable fractions of $\mathrm{C}$ in soil like L-C. This inverse relation is indicated in the PCA, where L-C posed oppositely to the treatment with fodder radish (Figure 2). It is also worth noting a stimulus to the activity of cellulase in 2008 in the soil cropped with fodder radish (Table 3), what may have resulted in decreased $\mathrm{R}-\mathrm{C}$ concentrations in 2009 due to contributions to $\mathrm{C}$ mineralization. Moreover, higher dehydrogenase activity in the same treatment (Table 3) suggest a more intensive microbial activity (BINI et al., 2014), leading to the oxidation of soil TOC. In addition, the activities of dehydrogenase and cellulase were associated to fodder radish cropping, and in a lesser extent, to the multicropping of cover crops, as observed in the PCA analysis (Figure 2). The treatment with wheat also decreased the L-C in 2009, as a possible result of a stimulus to the microbial activity mediated by root exudation during vegetative growth, followed by deposition of residues more resistant to degradation on the soil after harvest, with larger $\mathrm{C} / \mathrm{N}$ ratio, which makes more difficult the humification and formation of L-C. Lower concentrations of L-C in the soil cropped with fodder radish and wheat are in agreement with lower soil respiration, because microbial communities use more easily the more labile $\mathrm{C}$ fractions as substrate for growth and maintenance (BINI et al., 2013; BLAIR et al., 1995; KUWANO et al., 2014).

The higher $q \mathrm{Mic}$ in the soils cropped with fodder radish and the multicropping of cover crops in 2008 corroborates the information that such plant cover favor the MBC (Table 2), resulting in greater proportion of SOM as living microbial cells. The treatments did not affect the $q$ Mic in 2009 , but there was a decrease of about $30 \%$ in the soils cropped with fodder radish and the multicropping
Figure 2 - Principal component analysis (PCA) based on chemical, biochemical and microbiological attributes of a Rhodic Kandiudult as affected by different winter crops in a no-till cropping system under implantation, sampled in 2009 in Londrina PR. Chemical attributes ( $\mathrm{pH}, \mathrm{CEC}$, available $\mathrm{P}$ - P, bases saturation - V, total organic $\mathrm{C}-\mathrm{TOC}$, total $\mathrm{N}-\mathrm{TN}$ ), in bold, were employed as explanatory variables. Microbiological and biochemical attributes (Asparaginase activity - Asp, acid phosphatase - Fosf, cellulase - Cell, dehydrogenase - D-ase, urease - Ure, microbial activity - $\mathrm{CO}_{2}$, microbial biomass $\mathrm{C}$ $M B C$, labile $\mathrm{C}-L-C$, recalcitrant $\mathrm{C}-R-C$, microbial coefficient - qMic, microbial biomass $\mathrm{N}-M B N$ ), in italics, were used as response variables. Cover crops - multicropping of cover crops: black oat (Avena strigosa), hairy vetch (Vicia villosa) and fodder radish (Raphanus sativus); Ur - Urochloa ruziziensis intercropped with the main crop

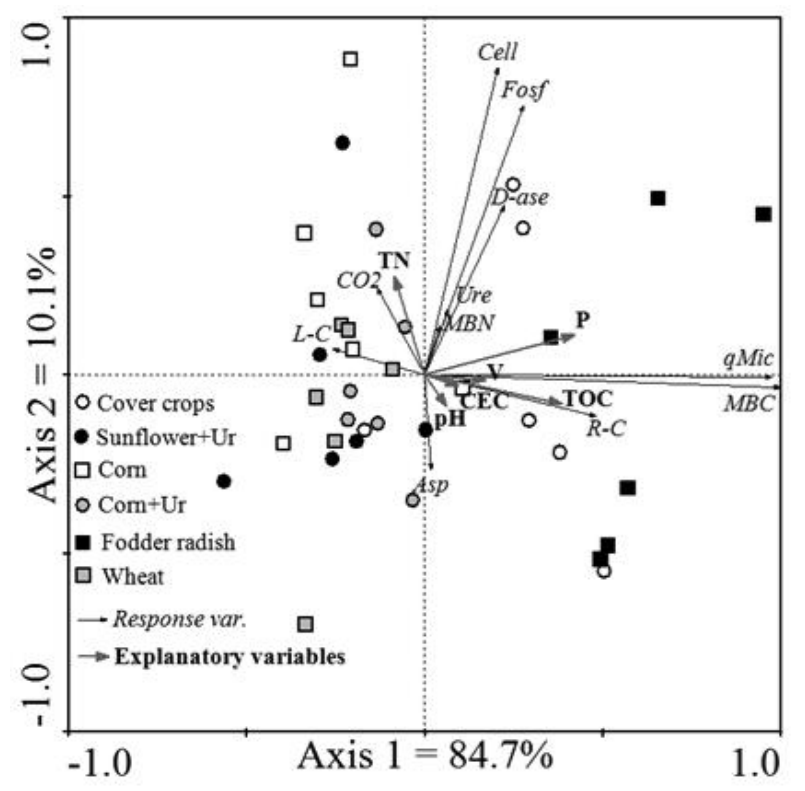

of cover crops in comparison to 2008. The microbial quotient $q \mathrm{Mic}$ is an indicator of SOM quality (KASCHUK et al., 2010), which values are consequence of the inputs of organic residues into the soil and the effectiveness of conversion to L-C (SPARLING, 1992). For this reason $q \mathrm{Mic}$ is regarded as indicator of organic $\mathrm{C}$ availability for soil microorganisms (GAMA-RODRIGUES et al., 2008). Values between 2 and 4.4\% are generally found in agricultural soils, depending on the climate, fertility, texture and management (ANDERSON, 2003), whereas values below $2 \%$ are regarded as critical in terms of soil quality. Despite higher values had been found in 2008, they were nearer the critical limit in 2009.

In 2008 , the total $\mathrm{N}$ was higher in the soil with fodder radish in comparison to the multicropping of cover crops and corn + Urochloa (Table 2). In 2009, the highest 
content was found in the soil cropped with sunflower + Urochloa, but differed only from the soil cropped with wheat. When comparing the cropping seasons, the total $\mathrm{N}$ in the soils cropped with fodder radish and wheat decreased by $14 \%$ and $17 \%$, respectively, from 2008 to 2009. Although these differences seems to be small, considering the most contrasting values in $2008,1.9 \mathrm{~g} \mathrm{~kg}^{-1}$ in the soil under corn + Urochloa, and $2.2 \mathrm{~g} \mathrm{~kg}^{-1}$ in the soil under fodder radish, considering the soil density as $1 \mathrm{~g} \mathrm{~cm}^{-3}$ at $0-10 \mathrm{~cm}$ depth, represents a difference of $300 \mathrm{~kg} \mathrm{ha}^{-1}$ more $\mathrm{N}$ in the soil with fodder radish. This highlights the capacity of fodder radish to get $\mathrm{N}$ from deeper soil layers and temporarily immobilize in the plant biomass and also in the microbial biomass after mineralization, corroborating the values for NMB in the soil with fodder radish in 2008 (Table 2). There was a slight change in the SOM C/N ratio in 2008, and a more marked change in 2009, where the lowest value was observed in the soil with sunflower + Urochloa (Table 2). Comparing between years, only the treatment with fodder radish decreased the SOM C/N ratio from 2008 to 2009, what might be consequence of decrease in R-C, and consequently, the TOC.

In 2008, the MBN changed in the same fashion as $\mathrm{MBC}$, with higher values in the soil with fodder radish and the multicropping of cover crops, whereas there was no effect in 2009. Nevertheless, comparing between years, MBN increased in 2009 in the soil with sunflower and corn, both intercropped with Urochloa, whereas a decrease was observed in the soil with the multicropping of cover crops and fodder radish. Higher MBN represents more $\mathrm{N}$ immobilized organically in microbial cells, keeping the $\mathrm{N}$ protected from losses by leaching or denitrification (FAGOTTI et al., 2012). The input of easily-degradable residues, in addition to favorable conditions due to more stable soil temperature and moisture resulting from the mulching in NTS, favor the microbial community (BINI et al., 2014; SILVA et al., 2007). Moreover, the $\mathrm{N}$ immobilized in microbial cells represents a reserve of $\mathrm{N}$ easily available, because is easily mineralized after microbial cells death, resulting in gradual $\mathrm{N}$ release to the production system (FRANK; GROFFMAN, 2009; SCHOMBERG; ENDALE, 2004). The potential for $\mathrm{N}$ mineralization (FRANKENBERGER; TABATABAI, 1991; SCHUSTER; SCHRODER, 1990) was evidenced in the soil with the multicropping of cover crops, with higher activities of asparaginase and ammonification, and also higher activities of acid phosphatase, involved in the mineralization of organic $\mathrm{P}$ (TABATABAI; BREMNER, 1969) (Table 3).

Despite the minor effects on soil chemical attributes (Table 1) and attributes related to $\mathrm{C}$ fractions in soil, including MBC (Table 3), the microbiological and biochemical attributes were more sensitive indicators of the winter crop effects (CARDOSO et al., 2013; GAMARODRIGUES et al., 2008). Sunflower + Urochloa stimulated the activity of urease, but the multicropping of cover crops decreased. Thus, the multicropping of cover crops seems more advantageous, because lower activity of urease is beneficial to the management of mineral $\mathrm{N}$ fertilization in the corn cropped in summer. A slower conversion of urea into ammonia lessens the risks of losses by volatilization, leaching as nitrate and denitrification (FAGOTTI et al., 2012). Additionally, the multicropping of cover crops increased the ammonification rate, whereas fodder radish and wheat decreased, similarly to the soil basal respiration. These results highlight the importance of the winter crops in acting as a reservoir not only for N (RANGEL; SILVA, 2007; SCHOMBERG; ENDALE, 2004), but also other nutrients to the summer crop. The treatments did not affect the nitrification rate.

The use of winter crops aims at the soil protection and formation of mulching, which is critical in the NTS. As consequence, there are improvements on physical, chemical and biological properties of soil, which lead to more stability along the cropping seasons some years after the adoption (FRANCHINI et al., 2012) and contribute to increase the sustainability of the production system (SILVA et al., 2008). Characteristics of species to be used as winter cops should include large production of biomass and straw mineralization synchronized with the demands of succeeding plants for nutrients (e.g. corn in the summer crop), besides soil protection and serving as $\mathrm{C}$ source for the microbial community, stimulating the $\mathrm{C}$ and nutrient cycle, and keeping or increasing the concentrations of SOM. Accordingly, the diversification of straw by using a consortium is promising, like observed for the multicropping of cover crops, in which the black oat contribute to produce biomass and immobilize nutrients, hairy vetch acts as $\mathrm{N}_{2}$-fixing plant, and fodder radish contribute to cycle $\mathrm{N}$, especially from deeper soil layers, like nitrate. Despite fodder radish as single winter crop had stimulated some microbiological and biochemical soil attributes, decreased the TOC in 2009, similarly to the wheat crop. Given that oxidic soils for long-term under conventional tillage have low contents of SOM, winter crops that contribute to increase the concentrations by means of higher inputs of residues are very helpful, especially at the beginning of the implantation of NTS.

\section{CONCLUSIONS}

1. The biological indicators of soil quality were positively affected in the short-term by the winter crops aiming at mulching, like the multicropping of cover crops (oat, hairy vetch and fodder radish) and fodder radish, but not the cash crops corn or wheat; 
2. Despite increasing soil microbiological and biochemical activities, fodder radish in single crop stimulated the decrease of soil organic carbon;

3. The use of different cover plant species in consortium showed to be promising for the implantation of no-till system, which, besides stimulating soil microbiological and biochemical attributes, also increased the concentrations of soil organic carbon.

\section{ACKNOWLEDGEMENTS}

To CAPES and CNPq for financial support and fellowships. To the group of Biometry at IAPAR for performing the univariate statistical analysis, and to Dra. Jenniffer Aparecida Schnitzer for helping the samplings in 2008. Approved for publication by the Editorial Board of Embrapa Soja as manuscript 13/2014.

\section{REFERENCES}

ALEF, K. Soil respiration. In: ALEF, K.; NANNIPIERI, P., Eds. Methods in Applied Soil Microbiology and Biochemistry. London, Academic Press, 1995. p. 214-219.

ANDERSON, T-H. Microbial eco-physiological indicators to assess soil quality. Agriculture, Ecosystems and Environment, v. 98 , n. 1-3, p. 285-293, 2003.

ANGHINONI, I. Fertilidade do solo e seu manejo em sistema plantio direto. In: NOVAIS, R. F. et al., Eds. Fertilidade do Solo. Viçosa, Sociedade Brasileira de Ciência doSolo, 2007. p. 873-928.

BLAIR, G. J.; LEFROY, R. D. B.; LISLE, L. Soil carbon fractions based on their degree of oxidation, and the development of a carbon management index for agricultural system. Australian Journal of Agriculture Research, v. 46, n. 7, p. 1459-1466, 1995.

BINI, D. et al. Identifying indicators of $\mathrm{C}$ and $\mathrm{N}$ cycling in a clayey Ultisol under different tillage and uses in winter. Applied Soil Ecology, v. 76, p. 95-101, 2014.

BINI, D. et al. Effect of land use on soil organic carbon and microbial processes associated with soil health in southern Brazil. European Journal of Soil Biology, v. 55, p. 117-123, 2013.

BREMNER, J. M.; MULVANEY, C. S. Nitrogen-total. In: PAGE, A. L.; MILLER, R. H. and KEENEY, D. R., Eds. Methods of Soil Analysis, part 2: Chemical and Microbiological Properties. Madison, American Society of Agronomy, 1982. p. 595-624.

BROOKES, P. C. et al. Chloroform fumigation and the release of soil nitrogen: a rapid direct extraction method to measure microbial biomass nitrogen in soil. Soil Biology and Biochemistry, v.17, p. 837-842, 1985.

CARDOSO, E. J. B. N. et al. Soil health: looking for suitable indicators. What should be considered to assess the effects of use and management on soil health? Scientia Agricola, v. 70, n. 4, p. 280-295, 2013.

CASIDA JR., L. E.; KLEIN, D. A.; SANTORO, T. Soil dehydrogenase activity. Soil Science, v. 98, p. 371-376, 1964.

CORDEIRO, M. A. S.; CORÁ, J. E.; NAHAS, E. Atributos bioquímicos e químicos do solo rizosférico e não rizosférico de culturas em rotação no sistema de semeadura direta. Revista Brasileira Ciência do Solo, v. 36, p. 1794-1803, 2012.

EMPRESA BRASILEIRA DE PESQUISA AGROPECUÁRIA. Manual de análises químicas de solos, plantas e fertilizantes. 2. ed. Brasília: Embrapa Informação Tecnológica, 2009. 627 p.

EMPRESA BRASILEIRA DE PESQUISA AGROPECUÁRIA. Sistema Brasileiro de Classificação de Solos. 2. ed. Rio de Janeiro: Embrapa Solos, 2006. 306 p.

FAGOTTI, D. S. L. et al. Gradients in N-cycling attributes along forestry and agricultural land-use systems are indicative of soil capacity for N supply. Soil Use and Management, v. 28, p. 292-298, 2012.

FRANCHINI, J. C. et al. Evolution of crop yields in different tillage and cropping systems over two decades in southern Brazil. Field Crops Research, v. 137, p. 178-185, 2012.

FRANK, D. A.; GROFFMAN, P. M. Plant rhizospheric N processes: what we don't know and why we should care. Ecology, v. 90, n. 6, p. 1512-1519, 2009.

FRANKENBERGER, W. T.; TABATABAI, M. A. Asparaginase activity of soils. Biology and Fertility of Soils, v. 11, p. 6-12, 1991.

GAMA-RODRIGUES, E. F. et al. Atributos químicos e microbianos de solos sob diferentes coberturas vegetais no norte do Estado do Rio de Janeiro. Revista Brasileira de Ciência do Solo, v. 32, n. 4, p. 1521-1530, 2008.

KASCHUK, G.; ALBERTON, O.; HUNGRIA, M. Three decades of soil microbial biomass studies in Brazilian ecosystems: Lessons learned about soil quality and indications for improving sustainability. Soil Biology and Biochemistry, v. 42, n. 1, p. 1-13, 2010.

KEENEY, D. R.; NELSON, D. W. Nitrogen inorganic forms. In: PAGE, A. L.; MILLER, R. H.; KEENEY, D. R., Eds. Methods of Soil Analysis, part 2: Chemical and Microbiological Properties. Madison, American Society of Agronomy, 1982. p. 643-698.

KUWANO, B. H. et al. Soil quality indicators in a Rhodic Kandiudult under different uses in Northern Paraná, Brazil. Revista Brasileira de Ciência do Solo, v. 38, n. 01, p. 5059,2014

NOGUEIRA, M. A. et al. Promising indicators for assessment of agroecosystems alteration among natural, reforested and agricultural land use in southern Brazil. Agriculture, Ecosystems and Environment, v. 115, p. 237-247, 2006.

PAVAN, M. A. et al. Manual de análise química de solo e controle de qualidade. Londrina: IAPAR, 1992. 39 p. (IAPAR. Circular, 76). 
RANGEL, O. J. P.; SILVA, C. A. Estoques de carbono e nitrogênio e frações orgânicas de Latossolo submetido a diferentes sistemas de uso e manejo. Revista Brasileira de Ciência do Solo, v. 31, n. 6, p. 1609-1623, 2007.

SCHINNER, F.; von MERSI. W. Xylanase-, CM-cellulase and invertase activity in soil: an improved method. Soil Biology and Biochemistry, v. 22, p. 511-515, 1990.

SCHOMBERG, H. H.; ENDALE, D. M. Cover crop effects on nitrogen mineralization and availability in conservation tillage cotton. Biology and Fertility of Soils, v. 40, n. 6, p. 398-405, 2004.

SCHUSTER, E.; SCHRODER, D. Side effects of sequentiallyapplied pesticides on target soil microorganisms: field experiments. Soil Biology and Biochemistry, v. 22, p. 367-373, 1990.

SILVA, A. A. et al. Desempenho agronômico e econômico do milho irrigado em sucessão a espécies invernais de cobertura de solo e/ou para produção de grãos. Ciência Rural, v. 38, n. 3 , p. $620-627,2008$.

SILVA, M. B. et al. Atributos biológicos do solo sob influência da cobertura vegetal e do sistema de manejo. Pesquisa Agropecuária Brasileira, v.42, n.12, p.1755-1761, 2007.

SPARLING, G. P. Ratio of microbial biomass carbon to soil organic carbon as a sensitive indicator of changes in soil organic matter. Australian Journal of Soil Research, v. 30, n. 2, p. 195-207, 1992.

TABATABAI, M. A.; BREMNER, J. M. Use of p-nitrofenol phosphate for assay of soil phosphatase activity. Soil Biology and Biochemistry, v.1, p. 301-307, 1969.

TABATABAI, M. A.; BREMNER, J. M. Assay of urease activity in soil. Soil Biology and Biochemistry, v. 4, n. 4, p. 479-487, 1972.

VANCE, E. D.; BROOKES, P. C.; JENKINSON, D. S. An extraction method for measuring soil microbial biomass C. Soil Biology and Biochemistry, v. 19, n. 6, p. 703-707, 1987. 